\title{
ARE ANTI-FOULING EFFECTS IN CORALLINE ALGAE SPECIES SPECIFIC?
}

\author{
Alexandre Bigio Villas Bôas* \& Marcia A. de O. Figueiredo** \\ Instituto de Pesquisas Jardim Botânico do Rio de Janeiro \\ (Rua Pacheco Leão 915, 222460-030, Rio de Janeiro, RJ, Brazil) \\ *alexbigio@hotmail.com -**aboas@jbrj.gov.br
}

\begin{abstract}
A B S T R A C T
The crustose coralline algae are susceptible to be covered by other algae, which in turn can be affected by anti-fouling effects. In this study the hypothesis tested was that these algae can inhibit the growth of epiphytes in a species specific way. In the laboratory, propagules of Sargassum furcatum and Ulva fasciata were liberated and cultivated on pieces of coralline algae and slide covers (controls) and their survival and growth were compared. Spongites and Hydrolithon significantly inhibited the growth of $U$. fasciata but not Sargassum. In the field, pieces of three species of live and dead coralline algae and their copies in epoxy putty discs were fixed on the rock. After one month epiphytic algae were identified and their dry mass quantified. Lithophyllum did not affect the epiphyte growth. In contrast Spongites and an unidentified coralline significantly inhibited the growth of Enteromorpha spp., Ulva fasciata and Hincksia mitchelliae. Colpomenia sinuosa was absent on all living crusts, but present on controls. Results show that the epiphyte-host relation depends on the species that are interacting. The sloughing of superficial cells of coralline crusts points to the possible action of physical anti-fouling effect, though a chemical one is not rejected.
\end{abstract}

\section{R ESUMO}

As algas calcárias crostosas são susceptíveis ao recobrimento por outras algas, entretanto, estas podem ser afetadas por efeitos anti-incrustantes. Neste estudo foi testada a hipótese de que estas algas possam inibir o crescimento somente de algumas espécies de epífitas. No laboratório, propágulos de Sargassum furcatum e Ulva fasciata foram liberados e cultivados sobre pedaços de algas calcárias e lamínulas de microscopia (controle) e as suas sobrevivência e crescimento comparadas. Spongites e Hydrolithon inibiram significativamente o crescimento de U. fasciata, mas não de Sargassum. No campo, pedaços de três espécies de algas calcárias vivas, mortas e cópias destas em discos de massa epóxi foram fíxos na rocha. Após um mês as algas epífitas foram identificadas e sua massa seca quantificada. Lithophyllum não inibiu o crescimento das epífitas, em contraste Spongites e outra coralinácea indeterminada inibiram o crescimento de Enteromorpha spp., Ulva fasciata e Hincksia mitchelliae. Colpomenia sinuosa esteve sempre ausente sobre as crostas vivas, porém presente nos controles. Resultados demonstram que a relação epífita-hospedeiro depende das espécies que estejam interagindo. $\mathrm{O}$ desprendimento de células superficiais das crostas coralináceas aponta para um possível efeito físico anti-incrustante, não se excluindo o químico.

Descriptors: Anti-fouling, Crustose coralline algae, Epiphytes, Rocky shore.

Descritores: Anti-incrustação, Algas calcárias incrustantes, Epífitas,Costão rochoso.

\section{INTRODUCTION}

The crustose coralline algae are perennial plants with prostrate habit, which turns them susceptible to be covered by other algae. Epiphytes can interfere with light incidence and nutrient absorption, reducing the photosynthesis and, consequently a plant's growth and reproduction (revision in Wahl, 1989). Epiphytes can be removed by wave splashing and sweeping by canopy algae (Hawkins \& Harkin, 1985; Kennely, 1989) or by herbivores action (Steneck \& Paine, 1986, 1990; Keats et al., 1994a; Figueiredo et al., 1996). Alternatively, host algae can present physical and chemical anti-fouling mechanisms able to control epiphytes development (Wahl, 1989).

The capacity to slough surface portions of the thallus, removing spores and recently established germlings has been demonstrated in several species of crustose coralline algae (Masaki et al., 1984; Johnson \& Mann, 1986; Keats et al., 1993, 1994b, 1997; Figueiredo et al, 1997). However, the possibility that 
chemical compounds produced by coralline algae are able to inhibit algae growth cannot be discarded (Figueiredo et al., 1997).

A previous study about seasonal colonisation on artificial substrata at Praia do Fôrno, Búzios (S22 46', O42 ${ }^{\circ} 3^{\prime}$ ), Rio de Janeiro State, Brazil, demonstrated that macroalgae species dispute space with coralline algae (Kátia Pereira dos Santos, pers. comm.*). Among these species, Colpomenia sinuosa (Roth) Derbès \& Solier and Sargassum furcatum Kuetz. are potential competitors, as they have opaque and thick thalli that can reduce incident light by up to 70\% (Hay, 1986), while filamentous and foliose algae (Cladophora spp., Enteromorpha spp. and Ulva fasciata Delile), with better photosynthetic performance and faster growth may limit the availability of nutrients for their plant host (Norton, 1991). Therefore, control of epiphytes by coralline algae could provide an advantage in competition for space, light and nutrients. In this study growth of different epiphytic algae will be tested in the presence of species of crustose coralline algae, in order to verify whether their anti-fouling effects are species specific.

\section{Methodology}

Coralline algae were identified at genus level, according to characteristics described by Woelkerling (1988), including features used to distinguish Spongites, Hydrolithon and Neogoniolithon (Penrose 1991, 1992; Penrose \& Woelkerling, 1992). Samples preserved in formalin were decalcified, embedded in resin (Leica Historesin) and sectioned by microtome for microscope analysis (methods in Moura et al., 1998). Generally, live plants were separated for experiments by their external morphology under the stereo microscope.

\section{LABORATORY EXPERIMENTS}

Samples of crustose coralline algae (Corallinaceae) and common epiphytic macroalgae were collected in the littoral and sublittoral zones of a rocky shore at Praia do Fôrno, Búzios, in the north of Rio de Janeiro State, Brazil. These plants were removed from the substratum with a hammer and chisel. Samples were maintained alive in a thermal box containing seawater and taken to the laboratory, where they were cleaned of epiphytes and animals with forceps and brush under a stereo microscope. Algae were stored in aquaria exposed to $20-22^{\circ} \mathrm{C}$ temperature, light intensity of $59-82 \mu \mathrm{mol} . \mathrm{m}^{-2} \cdot \mathrm{s}^{-1}$

(*)Santos, Kátia Pereira dos. 2002. Instituto de Pesquisas Jardim Botânico, Rio de Janeiro. (close to levels recommended for Sargassum by Paula, 1984 and for Ulvaceae by Fletcher, 1989) and periodicity of 12:12 hs light-darkness. Coralline crusts and epiphytes were cultured in Petri-dishes containing $15 \mathrm{ml}$ of filtered seawater $(0.45$ and $0.22 \mu \mathrm{m}$ pore $)$, sterilised in a microwave oven and enriched with $1 \%$ PES (Provasoli's culture medium, Starr \& Zeikus, 1993).

\section{Effects of Coralline Algae on Early Survival of Sargassum}

Oocyst liberation was induced in four culture dishes, each containing three fertile branches of different plants of $S$. furcatum. These were filled with $400 \mathrm{ml}$ of filtered and sterilised seawater, enriched with $4 \%$ PES. After one week, oocysts were liberated by fertile branches.

A variable number of oocysts were placed on the coralline algae Spongites sp. and Lithophyllum sp. and on slide covers (controls). For each treatment four replicates were used. Replicas were placed under laboratory controlled conditions of temperature and light. The experiment began on 08/27/98 and lasted four days. The number of live and dead oocysts were counted on the substrata using stereo microscope. The percentage survival data were arc-sin transformed in order to remove heterogeneity of variances (Underwood, 1997).

\section{Effects of Coralline Algae on Late Growth of Sargassum}

Three weeks old germlings of $S$. furcatum, differentiated into rhizoid, main axe and leaf-like blades, were placed on the coralline algae Hydrolithon sp. and Spongites sp. and slide cover controls. Because Lithophyllum sp. crusts had no effect on early survival of Sargassum, a different crust species was tested. Four replicates dishes, each with three germlings were prepared for each treatment. The experiment started on 09/03/98 and after one week the length (axis + blades) of one individual was measured in each dish, with the aid of a stereo microscope. Relative growth (RGR) was calculated using formula indicated by Evans (1972), where the difference of the logarithms of final and initial lengths is divided by the number of days of the experiment.

\section{Effects of Coralline Algae on the Growth of Ulva}

In 10/07/98 fertile material of $U$. fasciata was collected and kept in aquaria under laboratory conditions. After one week, plants initiated liberation of gametes / sporangium. Using a fine brush a piece of fertile alga with zoospores was placed on each coralline algae, Hydrolithon sp., Spongites sp. and control (petri-dishes without coralline). Four replicates were prepared for each treatment. The experiment 
began on 10/14/98. After one week the length of thirty individuals were measured on each coralline alga and control-dishes using a stereo microscope with magnification of 40x. Absolute growth was used instead of relative growth rate because it was not necessary to correct for size differences because it was assumed that zoospores had same mean size (Kain, 1987) and were numerous.

\section{FieLd EXPERIMENTS}

Effects of Coralline Algae on Epiphyte Colonisation

To test epiphytes colonisation on Spongites sp., Lithophyllum sp. and unidentified coralline algae, experiments were set up on 10/22/98 at Praia do Fôrno. The treatments were live crusts, dead crusts and copies made by epoxy (Multilit) with six replicates for each coralline species. The coralline algae were cut with wire cutter pliers to form discs with approximately $15 \mathrm{~mm}$ diameter, removing their natural rocky substratum. Organisms growing on crusts were also eliminated with the aid of forceps, plastic brushes and manual magnifying glass (10-20x). Some pieces of coralline alga were placed into the lids of film canisters, measuring $3 \mathrm{~cm}$ diameter, and stuck with epoxy. Other pieces were boiled and kept in freshwater overnight to obtain dead crusts. The control copies were made using dried pieces of coralline algae which had been fixed on discs with epoxy. These were covered with silicone rubber (Sylastic) in order to make a mould of the surface texture of crusts. This mould was used to make epoxy crust replicas.

In the field, groups of treatments with nine replicates were fixed using epoxy in six places along the rocky shore, in the lower littoral zone. After one month, crust discs were collected to quantify epiphytes. Each disc was removed from the substratum with a hammer and chisel, stored in film canisters containing seawater and taken to the laboratory. There, epiphytes removed from crusts using forceps were placed in Petri-dishes and identified under stereo microscope. Each sample's epiphytes were wrapped in aluminium foil, oven dried at $55^{\circ} \mathrm{C}$ overnight and weighed. Area of each coralline crust was measured to express epiphyte mass by unit area.

The effect of the coralline alga Spongites sp. on epiphyte growth was tested again in the field to confirm results, excluding the treatment with dead crusts. Algae collected on 01/07/99 were prepared and analysed according to methods described above, but using larger number of replicates $(n=9)$. Hydrolithon sp. was not tested in the field because it was difficult to find enough crusts naturally free of epiphytes, in contrast to Spongites sp. and Lithophyllum sp. which had surfaces mostly bare in spring and summer.

\section{Results}

Coralline algae were usually found covering littoral and sublitoral zones in the study site. Hydrolithon samoense (Foslie) Keats \& Chamberlain and Spongites sp. were abundant at upper levels and Lithophyllum sp. at lower levels on the shore. Coralline species could be easily distinguished by colour and external morphology in the field.

Spongites sp. is brownish, irregular to smooth surface and has leafy whitish margin. Thallus thickness was $250 \mu \mathrm{m}$. Cell fusions are present and secondary pit-conections are absent. Tetrasporangial conceptacle pores surrounded by vegetative cells orientated parallel to crusts surface. Tetrasporophytic conceptacles are uniporate, elevated, triangular shaped measuring 500-600 $\mu \mathrm{m}$ of external diameter and 450$500 \mu \mathrm{m}$ height. Gametangial conceptacles were not found, thus, genus identification remains uncertain. Crusts are found on the border of rock crevices together with species of Laurencia, Gelidium, Amphiroa and Cladophora.

Hydrolithon samoense has a pale pink colour, smooth surface, flat thallus and adherent margin. Cell fusions are present and secondary pit-conections are absent. Tetrasporangial conceptacle pores surrounded by vegetative cells orientated perpendicularly to crusts surface. Three cells layers in conceptacle roof are present. Tetrasporophytic conceptacles are uniporate, flush with the crust surface and bordered with a white ring measuring 100-225 $\mu \mathrm{m}$ of external diameter. Distinguishing characters of this species are given by Keats \& Chamberlain (1994). Crusts are found in the same area of Codium spongiosum Harvey, eventually being covered by it.

Lithophyllum sp. has a dark purple colour, smooth surface and large protuberances measuring 0.5 to $1.5 \mathrm{~mm}$ of diameter and 3 to $4 \mathrm{~mm}$ height. Tetrasporophytic conceptacles are uniporate, elevated, round shaped measuring 240-300 $\mu \mathrm{m}$ in external diameter. Cell fusions are absent and secondary pitconection present. Crusts are found beneath canopies of Sargassum furcatum.

Corallinaceae unidentified has light purple colour, smooth surface and thallus flat to slightly protuberant. Crusts are found in tide pools covered by Ulva and Enteromorpha spp.

\section{LABORATORY EXPERIMENTS}

Discharges of oocysts of $S$. furcatum and gametes/spores of $U$. fasciata were successfully induced after one week plants initiated liberation of gametes/spores. 
Early post-settlement stages of $S$. furcatum showed a stronger tendency for lower survival on the coralline algae Spongites sp and lesser so on Lithophyllum sp. in relation to the control, although these differences were not significant (Fig.1; Tab.1). Similarly, the growth of juveniles of $S$. furcatum did not differ either on Hydrolithon samoense or Spongites sp. in relation to the control (Fig. 2; Tab. 2). However, the growth of $U$. fasciata was significantly lower on H. samoense and Spongites sp. when compared to the control (Fig. 3; Tab. 3).

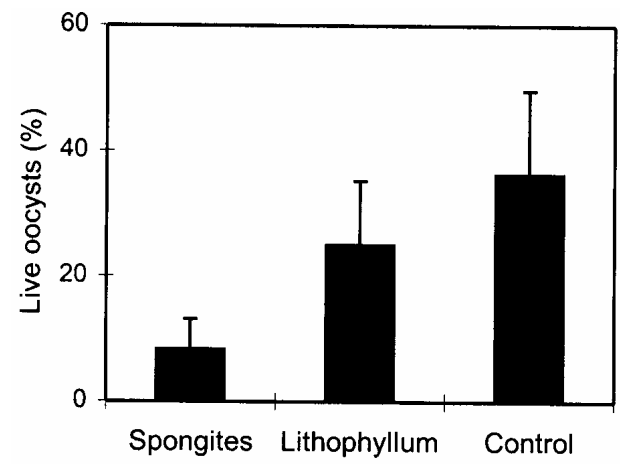

Fig. 1. Survival of $S$. furcatum oocysts on Spongites and Lithophyllum crusts and control. Mean \pm standard error.

Table 1. Analysis of variance for the survival of $S$. furcatum on Spongites and Lithophyllum crusts and controls.

\begin{tabular}{lcccc}
\hline \hline Anova & df & MS & F & $p$ \\
\hline Among groups & 2 & 0,17 & 2,02 & 0,18 \\
Within groups & 9 & 0,08 & & \\
Total & 11 & & & \\
& & & & \\
\hline
\end{tabular}

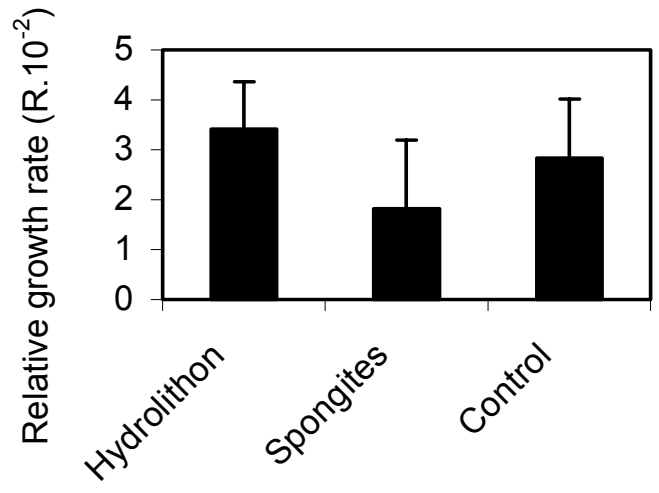

Fig. 2. Relative growth rate (R) of juveniles $S$. furcatum on Hydrolithon and Spongites crusts and control. Mean \pm standard error.
Table 2. Analysis of variance for relative growth rate of $S$ furcatum on Spongites and Hydrolithon crusts and controls.

\begin{tabular}{lcccc}
\hline \hline Anova & df & MS & F & $p$ \\
\hline Among groups & 2 & 0,00 & 0,47 & 0,63 \\
Within groups & 9 & 0,00 & & \\
Total & 11 & & & \\
\hline
\end{tabular}

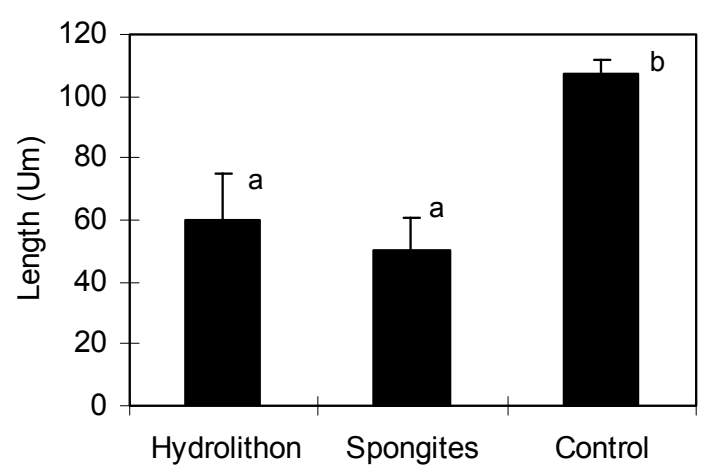

Fig. 3. Absolute growth rate of $U$. fasciata on Hydrolithon and Spongites crusts and control.. Mean \pm standard error. Different letters above bars indicate significant differences.

Table 3. Analysis of variance for absolute growth of $U$. fasciata on Spongites and Hydrolithon crusts and controls.

\begin{tabular}{lcccc}
\hline \hline Anova & df & MS & F & $p$ \\
\hline Among groups & 2 & 3690 & 7,71 & 0,01 \\
Within groups & 9 & 478,1 & & \\
Total & 11 & & & \\
\hline
\end{tabular}

Field Experiments

In the spring field experiments, epiphytes had a strong tendency for lower growth on live Spongites sp. in relation to control (Fig. 4a; Tab. 4a). Epiphytes on Lithophyllum sp. also showed a trend for lower growth on live crusts, but the results were not significant (Fig. 4b; Tab. 4b). Epiphytes on unidentified coralline alga had a significantly lower growth on live crusts (Fig. 4c; Tab. 4c). Dead crusts usually bore as many epiphytes as epoxy replicas, showing that the later were good controls for live crusts. The most common epiphytes found colonising crusts were: Enteromorpha spp., U. fasciata and Hincksia mitchelliae (Harv.) P. C. Silva on all coralline species, either on live, and dead or epoxy replicas. However, Colpomenia sinuosa was frequently found on dead and epoxy replicas of all three coralline species, being practically absent on live crusts.

When repeating the experiment with Spongites sp., in summer, less epiphyte growth was again observed on live crusts compared to control (Fig. 5; Tab. 5). This significant difference confirms the tendency found in the previous experiment. 

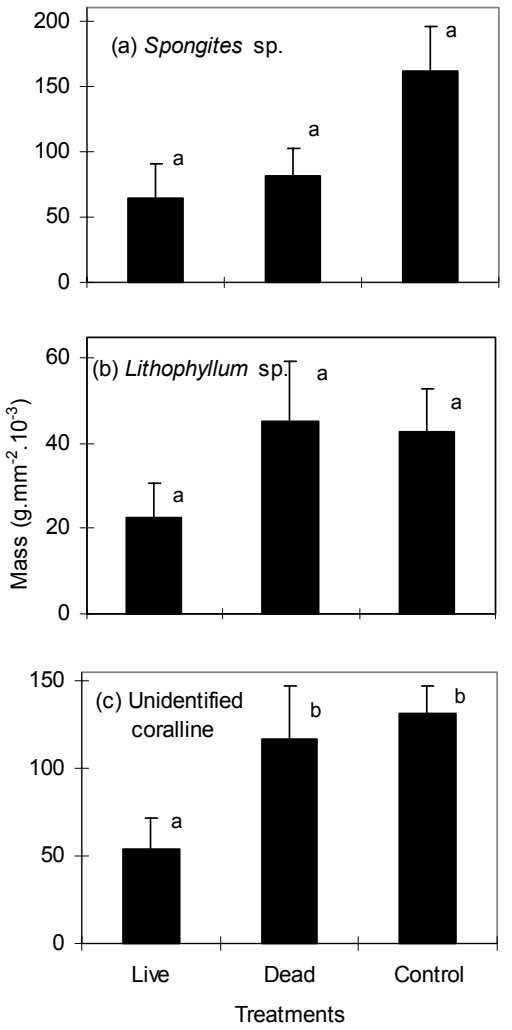

Fig. 4. Epiphyte growth on live, dead and epoxy copies of Spongites sp. (a), Lithophyllum sp. (b) and unidentified coralline algae (c) in spring. Mean \pm standard error. Different letters above bars indicate significant differences.

Table 4. Analysis of variance of epiphytes growth on Spongites (a), Lithophyllum (b) and an unidentified coralline algae (c) in the field.

\begin{tabular}{lrrcc}
\hline \hline Anova & df & MS & F & $p$ \\
\hline Among groups & 2 & 0,01 & 3,50 & 0,058 \\
Within groups & 14 & 0,00 & & \\
Total & 16 & & & \\
\hline
\end{tabular}

(b)

$\begin{array}{lrrrr}\text { Among groups } & 2 & 0,00 & 1,26 & 0,31\end{array}$

Within groups $\quad 15 \quad 0,00$

Total 17

(c)

Among groups $\quad 2 \quad 0,01 \quad 4,27 \quad 0,03$

Within groups $12 \quad 0,00$

Total 14

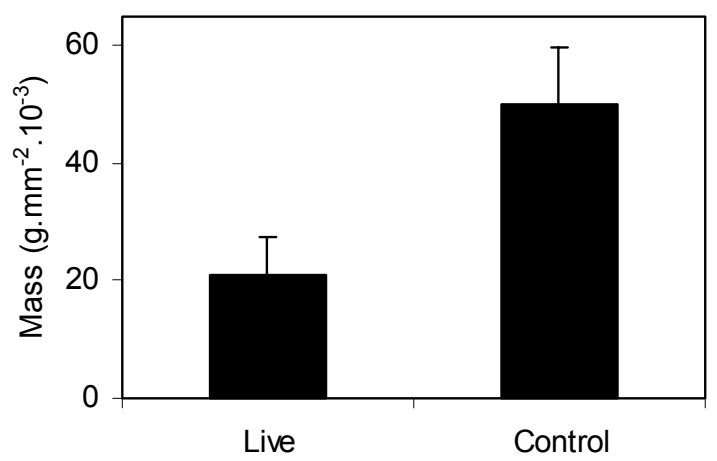

Fig. 5. Epiphyte growth on live and epoxy copies (controls) of Spongites in summer. Mean \pm standard error.

Table 5. Analysis of variance of epiphytes growth on Spongites in the field.

\begin{tabular}{lrrcc}
\hline \hline Anova & df & MS & F & $p$ \\
\hline Among groups & 1 & 0,00 & 6,57 & 0,02 \\
Within groups & 15 & 0,00 & & \\
Total & 16 & & & \\
\hline
\end{tabular}

\section{Discussion}

In the studied area, coralline algae covered most substrata and determined community composition on the shore. Among epiphytic algae, Ulvales were commonly found as early colonisers on the coralline algae Hydrolithon and Spongites in the littoral zone. The macroalga Sargassum was more abundant in the sublittoral, where it shared space with the coralline alga Lithophyllum. It is known that substratum topography can facilitate settlement and survival of algae depending on the size of propagules in relation to surface depressions (Vadas et al., 1992). In this context, Spongites would be more likely covered by Ulvales and Lithophyllum by Sargassum since their zoospores and oocysts measure about 8-10 $\mu \mathrm{m}$ (Fletcher, 1989) and $45 \mu \mathrm{m}$, respectively, and the irregular surface of the former and protuberant surface of the later provide enough space for their establishment (Norton \& Fetter, 1981). In fact, epoxy replicas of Spongites supported three times more Ulvales than replicas of Lithophyllum, probably due to smaller propagules being better protected in smaller depressions from dislodgement by water motion (Fletcher \& Callow, 1992). A similar result was found by Figueiredo et al. (1997) for two species of coralline algae which were different both in their topography and in relation to propagule size of epiphyte species. 
Despite the fact that morphology of crusts' surfaces may enhance epiphyte colonisation, corallines can compensate, removing them by sloughing superficial cells. In the laboratory, the coralline algae Spongites sp. had a strong tendency to reduce the number of early post settlement stages of $S$. furcatum, but the coralline algae Lithophyllum sp. did not interfere with their survival. In late development phases of $S$. furcatum, neither the coralline alga Spongites sp. nor Hydrolithon managed to inhibit these juveniles from growing. Therefore, the successful establishment of juveniles is determined early or soon after settlement; otherwise, juveniles tend to swamp the coralline algae. In later stages of development, $S$. furcatum holdfasts seem to exclude coralline algae beneath, maybe by reducing incident light (by up to $70 \%$, Hay, 1986). A few studies have demonstrated that the growth of some coralline species can be limited when there is a drastic reduction in the light intensity (Williams \& Carpenter, 1990; Figueiredo et al., 2000). In this case, a possible antifouling effect of coralline algae would give them an advantage by inhibiting settlement of this subsequently competitively superior epiphyte.

In the field, Spongites sp. and an unidentified coralline algae inhibited epiphyte growth, mainly of foliose and filamentous algae such as Enteromorpha, Ulva and Hincksia, contrasting with Lithophyllum sp. that did not inhibit their growth. This result agrees with the previous laboratory experiment, where Spongites sp. and Hydrolithon samoense negatively affected $U$. fasciata growth. The control of Ulvales may represent an advantage for the coralline algae, because these epiphytes have fast growth rates and can compete for nutrients and light when forming dense cover (Norton et al., 1982; Figueiredo et al., 2000). Colpomenia was absent on all species of living crusts in the field experiment and it is another potential competitor because its foliose opaque thallus shade as much as Sargassum (Hay, 1986). However, both these filamentous and foliose algae are ephemeral plants that soon complete their life cycles, leaving coralline surfaces free of epiphytes.

Some environmental factors that can inhibit epiphyte growth are herbivory, wave action in shallow and tidal zones and shading in caves, deep water and beneath macroalgae (Steneck, 1997). In the studied area, the littoral zone is sheltered and water movement may be less important than grazing. Potential herbivores are juvenile Echinometra sea urchins which forms numerous groups on the lower shore and are able to scrape within crevices. In the early stages of recruitment, most macro grazers are not effective consumers as they are not capable of reaching propagules within the irregular surfaces (Menge et al., 1985; Figueiredo et al., 1996). However, ephemeral algae, such as Ulvales, were able to quickly colonise crusts surfaces where urchins were commonly found. In contrast, although fertile at the time, Sargassum was never found colonising experimental crusts maybe because grazers more effective remove this slow growing algae than the fast growing ones (reviewed in Hoffman, 1987).

One mechanism of coralline algae of self defence against epiphytes is sloughing of epithallial cells, a characteristic found in several species (Steneck \& Paine, 1986). In the studied genera, sloughing has been described for terminal epithallial cells in Spongites yendoi (Foslie) Chamberlain and Hydrolithon onkodes (Heydrich) Penrose et Woelkerling (Keats et al., 1993; 1994b, 1997) and superficial and deep layer cells in Lithophyllum incrassatum (Foslie) Foslie, L. neoatalayense Masaki and L. impressum Foslie (Chamberlain, 1996; Pueschel et al., 1996; Puechel \& Keats, 1997). Epithallial shedding has been demonstrated to be non synchronous in $H$. onkodes and simultaneous across a large area of thallus in Sporolithon ptychoides Heydrich and Neogoniolithon fosliei (Heydrich) Setchell \& Mason (Keats et al., 1997).

Our results indicate that anti-fouling is probably physical, due to observations of cells sloughing on the superficial layers of all studied coralline crusts. Because superficial sloughing may result from growth processes (Puechel et al., 1996; Puechel \& Keats, 1997) and thinner crusts grow faster (Steneck, 1986), we suggest that Spongites and Hydrolithon are more effective anti-foulers. Epiphyte growth was shown to be lower on live Hydrolithon and Spongites in relation to controls, which also suggests a chemical effect. However, the possibility of chemical anti-fouling activity was not tested and cannot be excluded yet. There were different responses of epiphyte species in relation to the studied coralline hosts, which supports the hypothesis that anti-fouling effects are species specific.

\section{AcKNowledgements}

We thank the Research State Agency of Rio de Janeiro for the Scientific Initiation scholarship for the first author (FAPERJ process E-26/150.104/98) and to the National Research Council for a grant to the senior author (CNPq process 523245/96-3). We are also grateful to D. W. Keats for confirming the identification of $H$. samoense and to $\mathrm{G}$. Maneveldt and Carmen Ras for assistance with electron microscopy analysis, which were carried out in the University of the Western Cape thanks to grants from CNPq (452482/01-1) and FAPERJ (E26/171.034/01). 


\section{References}

Chamberlain, Y. M. 1996. Lithophylloid Corallinaceae (Rhodophyta) of the genera Lithophyllum and Titanoderma from southern Africa. Phycologia, $35: 204-221$

Evans, G. C. 1972. The quantitative analysis of plant growth. Oxford, Blackwell. 734p.

Figueiredo, M. A. O.; Kain, J. M. \& Norton, T. A. 1996. Biotic interactions in the colonisation of crustose coralline algae by epiphytes. J. expl. mar. Biol. Ecol., 199:303-318.

Figueiredo, M. A. O.; Norton, T. A. \& Kain, J. M. 1997. Settlement and survival of epiphytes on two intertidal crustose coralline alga. J. expl. mar. Biol. Ecol., 213(2):247-260.

Figueiredo, M. A. O.; Kain, J. M. \& Norton, T. A. 2000. Responses of crustose corallines to epiphyte and canopy cover. J. Phycol., 36(1):17-24.

Fletcher, R. L. 1989. A bioassay technique using the marine fouling green alga Enteromorpha. International Biodeterioration, 25(6):407-422.

Fletcher, R. L. \& Callow, M. E. 1992. The settlement, attachment and establishment of marine algal spores. Br. phycol. J., 27(3):303-329.

Hawkins, S. J. \& Harkin, E. 1985. Preliminary canopy removal experiments in algal dominated communities low on the shore and in the shallow subtidal on the Isle of Man. Botanica mar., 28(6):223-230.

Hay, M. E. 1986. Functional geometry of seaweeds: ecological consequences of thallus layering and shape in contrasting light environments. In: Givnish, T. J. ed. On the economy of plant form and function. Cambridge, Cambridge University Press. p.635-666.

Hoffman, A. J. 1987. The arrival of seaweed propagules at the shore: a review. Botanica mar., 30:151-165.

Johnson, C. R. \& Mann, K. H. 1986. The crustose coralline alga Phymatolithon Foslie inhibits the overgrowth of seaweeds without relying on herbivores. J. expl. mar. Biol. Ecol., 96(2):127-146.

Kain, J. M. 1987. Seasonal growth and photoinhibition in Plocamium cartilagineum (Rhodophyta) off the Isle of Man. Phycologia, 26:88-99.

Keats, D. W.; Groener, A. \& Chamberlain, Y. M. 1993. Cell sloughing in the littoral zone coralline alga Spongites yendoi (Foslie) Chamberlain (Corallinales, Rhodophyta). Phycologia, 32(2):143-150.

Keats, D. W. \& Chamberlain, Y. M. 1994. Three species of Hydrolithon (Rhodophyta, Corallinaceae): Hydrolithon onkodes (Heydrich) Penrose and Woelkerling, Hydrolithon superficiale sp. nov., and $H$. samoënse (Foslie) comb. Nov. from South Africa. S. Afr. J. Bot., 60(1):8-21.

Keats, D. W.; Matthews, I. \& Maneveldt, G. 1994a. Competitive relationships and coexistence in the guild of crustose algae in the eullitoral zone, Castrate Province, South Africa. S. Afr. J. Bot., 60(2):108-113.

Keats, D. W.; Wilton, P. \& Maneveldt, G. 1994b. Ecological significance of deep-layer sloughing in the eulittoral zone coralline alga, Spongites yendoi (Foslie) Chamberlain (Corallinaceae, Rhodophyta). J. expl. mar. Biol. Ecol., 175(2):145-154.
Keats, D. W.; Knight, M. A. \& Pueschel, C. M. 1997. Antifouling effects of epithallial shedding in three crustose coralline algae (Rhodophyta, Corallinales) on a coral reef. J. expl. mar. Biol. Ecol., 213(2):281293.

Kennelly, S. J. 1989. Effects of kelp canopies on understory species due to shade and scour. Mar. Ecol. Progr. Ser., 50(3):215-224.

Masaki, T.; Fujita, D. \& Hagen, N. T. 1984. The surface ultrastructure and epithallium shedding of crustose coralline algae in an "isoyake" area of southwestern Hokkaido, Japan. Hydrobiologia, 116(Sep):218-223.

Menge, B. A.; Lubchenco, J. \& Ashkenas, L. R. 1985. Diversity, heterogeneity and consumer pressure in a tropical rocky intertidal community. Oecologia, 65(3):395-405.

Moura, C. W. do N.; Kraus, J. E. \& Cordeiro-Marino, M. 1998. Metodologia para obtenção de cortes histológicos com historesina e coloração com azul de toluidina $\mathrm{O}$ para algas coralináceas (Rhodophyta, Coralinales). Hoehnea, 24:17-27.

Norton, T. A.; Mathieson, A. C. \& Neushul, M. 1982. A review of some aspects of form and function in seaweeds. Botanica mar., 25(11):501-510.

Norton, T. A. 1991. Conflicting constraints on the form of intertidal algae. Br. phycol. J., 26(3):203-218.

Norton, A. T. \& Fetter, R. 1981. The settlement of Sargassum muticum propagules in stationery and flowing water. J. mar. biol. Ass. U. K., 61(4):929-940.

Paula, E. J. 1984. Estudos experimentais de cultivo e hibridação em Sargassum (Phaeophyta - Fucales) em condições de laboratório. $\mathrm{PhD}$ thesis. Universidade de São Paulo. 246p.

Penrose, D. 1991. Spongites fruticulosus (Corallinaceae, Rhodophyta), the type species of Spongites in southern Australia. Phycologia, 30(5):438-448.

Penrose, D. 1992. Neogoniolithon fosliei (Corallinaceae, Rhodophyta), the type species of Neogoniolithon in southern Australia. Phycologia, 31(3-4):338-350.

Penrose, D. \& Woelkerling, W. J. 1992. A reapraisal of Hydrolithon (Corallinales, Rhodophyta) and its relationships to Spongites. Phycologia, 31(1):81-88.

Pueschel, C. M.; Miller, T. J. \& McCausland, B. B. 1996 Development of epithallial cells in Corallina officinalis and Lithophyllum impressum (Corallinales, Rhodophyta). Phycologia, 35:161-169.

Pueschel, C. M. \& Keats, D. W. 1997. Fine struture of deeplayer sloughing and epithallial regeneration in Lithophyllum neoatalayense (Corallinales, Rhodophyta). Phycological Res., 45:1-8.

Starr, R. C. \& Zeikus, J. A. 1993. UTEX - The culture collection of algae at the University of Texas at Austin. J. Phycol., 29(suppl.):1-106.

Steneck, R. S. 1990. Herbivory and the evolution of nongeniculate coralline algae (Rhodophyta, Corallinales) in the North Atlantic and North Pacific. In: Garbary D. J. \& South G. R. eds. Evolutionary biogeography of the marine algae of the North Atlantic. Berlin, Springer-Verlag. p.107-129.

Steneck, R. S. \& Paine, R. T. 1986. Ecological and taxonomic studies of shallow-water encrusting Corallinaceae (Rhodophyta) of the northerly northeastern Pacific. Phycologia, 25:221-240. 
Steneck, R. S. 1997. Crustose corallines, other algal functional groups, herbivores and sediments: complex interactions along reef productivity gradients. In: Lessios, H. A. \& Macintyre, I.G. eds. Proceedings of the $8^{\text {th }}$ International Coral Reef Symposium v.1, p.695709 .

Underwood, A. J. 1997. Experiments in ecology. Their logical design and interpretation using analysis of variance. Cambridge, Cambridge University Press. $504 \mathrm{p}$.

Vadas, R. L.; Johnson, S. \& Norton, T. A. 1992. Recruitment and mortality of early post-settlement stages of benthic algae. Br. Phycol. J., 27(3):331-351.

Wahl, M. 1989. Marine epibiosis. 1. Fouling and antifouling: some basics aspects. Mar. Ecol. Progr. Ser., 58:175189.
Williams, S. L. \& Carpenter, R. C. 1990 Photosynthesis/photon flux density relationships among components of coral reef algal turfs. J. Phycol., 26(1):36-40.

Woelkerling, W. J. 1988. The coralline red algae: an analysis of the genera and subfamilies of nongeliculate Corallinaceae. Oxford, Oxford Univ. Press. 268p.

(Manuscript received 21 February 2002; revised 12 March 2003; accepted 19 September 2003) 